\title{
Post Impact Evaluation on Jiangsu Inland Waterway Infrastructure Projects
}

\author{
Zhenyu Liu ${ }^{1, a^{*}}$ and Xiaojian Wang ${ }^{2, b}$ \\ ${ }^{1,2}$ Wuxi waterways management division, No. 128 Canal Road, Wuxi, China
}

a361168375@qq.com

Keywords: Inland waterway infrastructure; Indicator system; Post-evaluation project; Gray cluster analysis.

\begin{abstract}
On considering of the current study of Jiangsu inland waterway infrastructure construction projects and the features of these projects, this study put an indicator system on post-evaluation work of inland waterway infrastructure construction based on their overall thoughts. The indicator systems were made through four parts of the projects, construction process, economic effectiveness, engineering effeteness and sustainable development, and relative post-evaluation methods were given. For there's more qualitative evaluation indexes and the incompetence of the data, the grey fuzzy evaluation method was used in this study. With an improved method on the existing endpoints triangular whitenization weight function and center triangular whitenization weight function, center triangular whitenization weight function became more scientific and reasonable. The study has been used in the post-evaluation project of level-3 waterway regulation project of Sunan Canal (Wuxi Section).
\end{abstract}

\section{Introduction}

The evaluation after the project produced in western developed countries, it began in the 1930s, according to the different needs of each stage of the evaluation, evaluate the project from every angle. Include process evaluation of the project, the project's technical and economic evaluation, impact evaluation of the project, the project's social evaluation. And it also created a logical framework approach, with or without contrast method, analytic, causal analysis, comprehensive evaluation, success evaluation method and practical methods. Most importantly, each developed country, according to national conditions, establishes a set of post evaluation system adapted to their needs, and the establishment of appropriate regulations to guarantee the implementation. Foreign scholars on the project post evaluation theory research and practice. Kahn and Wiener proposed analysis method in the order ${ }^{[1]}$, France put forward regional development plan should be used to order law and order trends method ${ }^{[2]}$. Daddario technical evaluation method is proposed, according to the needs of policy makers measure the impact of technology on society ${ }^{[3]}$. Scholars such as Campbell and Esselman operate on a project life of aging issues, proposed life-cycle management mode and method ${ }^{[4]}$. W.Ronald life-cycle project management point of view, while considering the project construction cost and cost, select the lowest-cost optimization programme ${ }^{[5]}$. Xiao y, lack of project evaluation index system in oil field based on factor analysis method using indexing and classification, and laid the Foundation effective oilfield ground construction project post-evaluation ${ }^{[6]}$. Not only that, but some international financial organizations have also established their own perfect characteristics of evaluation mechanism ${ }^{[7-9]}$, for example, we are most familiar with the World Bank, according to their own needs, from their point of view, established an independent evaluation mechanism, and widely used in all World Bank loan project in the world, has achieved good results ${ }^{[10]}$. This evaluation considers the waterway infrastructure construction projects of social and economic benefits, and the importance of environmental impact assessment. Waterway infrastructure construction projects abroad succeed in the evaluation process, the active involvement of the Government is the most important factor. Active government participation are waterway infrastructure construction project post-evaluation fundamental guarantee for successfully developing. Inland waterway infrastructure projects are public interest, belonging to public goods, 
and its main function is to provide services for the community. The Government as the main provider of public goods, in order to guarantee their quality and functional effects on the one hand, on the administration of inland waterway infrastructure construction should be planning, evaluation, monitoring, and so on. In other countries, most of the inland waterway infrastructure projects related to the evaluation process, the Government always in the leading position, ensured the fair and smooth of the evaluation.

\section{Post Evaluation Model}

On the basis of the content and features of literature reading method, frequency analysis, attribute reduction method, the results of reference method, determine the inland waterway in Jiangsu province infrastructure construction project post-evaluation index system, with canal in Wuxi section level 3 waterway regulation project in the south of Jiangsu for instance, characteristic values and weights of each evaluation index such as shown in Table 1.

Table 1 Post evaluation index system

\begin{tabular}{|c|c|c|c|c|}
\hline \multicolumn{2}{|c|}{ Criterion layer } & \multicolumn{3}{|c|}{ Index layer } \\
\hline Sub criterion & weight & Index & weight & value $\%$ \\
\hline \multirow{6}{*}{ Process } & \multirow{6}{*}{0.2} & Policy compliance & 0.2 & 90 \\
\hline & & $\begin{array}{l}\text { Standard degree of demonstration } \\
\text { process }\end{array}$ & 0.2 & 97 \\
\hline & & construction period & 0.15 & 90 \\
\hline & & Completeness of management & 0.10 & 88 \\
\hline & & contract performance & 0.15 & 80 \\
\hline & & Bidding process improvement & 0.2 & 95 \\
\hline \multirow{3}{*}{ Economic benefit } & \multirow{3}{*}{0.15} & Economic internal rate of return & 0.40 & 100 \\
\hline & & Economic Net Present Value & 0.30 & 96 \\
\hline & & Economic benefit cost ratio & 0.30 & 98 \\
\hline \multirow{9}{*}{$\begin{array}{l}\text { Engineering } \\
\text { influence }\end{array}$} & \multirow{9}{*}{0.5} & Cargo transport volume & 0.15 & 95 \\
\hline & & rate of high-grade channel & 0.10 & 90 \\
\hline & & Average tonnage of ship & 0.10 & 93 \\
\hline & & Energy saving quantity & 0.10 & 97 \\
\hline & & Emission reduction benefit & 0.15 & 100 \\
\hline & & $\begin{array}{c}\text { Comprehensive utilization rate of } \\
\text { earthwork }\end{array}$ & 0.15 & 100 \\
\hline & & afforested area & 0.15 & 98 \\
\hline & & Resident life satisfaction & 0.05 & 100 \\
\hline & & $\begin{array}{c}\text { Satisfaction of immigrant } \\
\text { settlement }\end{array}$ & 0.05 & 97 \\
\hline \multirow{4}{*}{$\begin{array}{l}\text { Capacity of } \\
\text { sustainable } \\
\text { development }\end{array}$} & \multirow{4}{*}{0.15} & Completion status & 0.25 & 100 \\
\hline & & Completeness of mechanism & 0.25 & 100 \\
\hline & & Sustainability of funds & 0.25 & 89 \\
\hline & & Policies sustainability & 0.25 & 85 \\
\hline
\end{tabular}

According to the assessment requirements it will be divided into "poor", "general", "good", "very good". The grey interval is shown in Table 2.

Table 2 division of Grey interval

\begin{tabular}{|c|c|c|c|}
\hline bad & general & good & Very good \\
\hline $65 \leq x_{12}<75.5$ & $75.5 \leq x_{12}<92.5$ & $89 \leq x_{12}<97$ & $95.5 \leq x_{12}<100.5$ \\
\hline
\end{tabular}

The membership degree of index can be calculated and the coefficient of $x_{11}$ is shown as follows. 


$$
f_{1}^{1}\left(x_{11}\right)=\left\{\begin{array}{lc}
0, & x_{11} \notin[65,75.5), \\
\frac{x_{11}-65}{70-65}, & x_{11} \in[65,70), \\
\frac{75.5-x_{11}}{75.5-70}, & x_{11} \in[70,75.5),
\end{array}\right.
$$

$$
f_{1}^{2}\left(x_{11}\right)= \begin{cases}0, & x_{11} \notin[75.5,92.5), \\ \frac{x_{11}-75.5}{85-75.5}, & x_{11} \in[75.5,85), \\ \frac{92.5-x_{11}}{92.5-85}, & x_{11} \in[85,92.5),\end{cases}
$$

$$
f_{1}^{3}\left(x_{11}\right)= \begin{cases}0, & x_{11} \notin[89,97), \\ \frac{x_{11}-89}{93-89}, & x_{11} \in[89,93), \\ \frac{97-x_{11}}{97-93}, & x_{11} \in[93,97),\end{cases}
$$

$$
f_{1}^{4}\left(x_{11}\right)= \begin{cases}0, & x_{11} \notin[95.5,100.5), \\ \frac{x_{11}-95.5}{98-95.5}, & x_{11} \in[95.5,98), \\ \frac{100.5-x_{11}}{100.5-98}, & x_{11} \in[98,100.5),\end{cases}
$$

Table 3 Clustering coefficient of index

\begin{tabular}{|c|l|c|c|c|c|}
\hline grey & $x_{1}$ & $x_{2}$ & $x_{3}$ & $x_{4}$ & $x$ \\
\hline bad & 0.009 & 0 & 0.014 & 0 & 0.005 \\
\hline general & 0.188 & 0.475 & 0.125 & 0 & 0.216 \\
\hline good & 0.189 & 0 & 0.416 & 0.367 & 0.228 \\
\hline Very good & 0.143 & 0.36 & 0.046 & 0.1 & 0.175 \\
\hline
\end{tabular}

$\max _{1 \leq k \leq 4}\left\{\sigma^{k}\right\}=\sigma^{3}=0.228$, The result of evaluation about South of Jiangsu canal Wuxi section is good.

\section{Summary}

This paper is focus on inland waterway infrastructure construction project post-evaluation of comprehensive evaluation method which is discussed, the conclusion is as follows. According to the inland waterway in JiangSu province and after the construction of infrastructure project characteristics, this paper established the inland waterway infrastructure construction project post-evaluation index system, and choose the suitable evaluation methods for each individual after evaluation. He qualitative indicators of inland waterway infrastructure construction project evaluation is too many, the gray clustering evaluation method to quantify the qualitative indexes, to avoid the subjectivity in evaluation. It is more appropriate to apply it to the inland waterway in the infrastructure construction project post-evaluation, and it has certain practical significance. 


\section{Acknowledgements}

This paper is funded by "Research on the post evaluation criterion of Jiangsu inland waterway infrastructure construction project" (Project of research on traffic science of Jiangsu Province , Item number 2013Y17).

\section{References}

[1] Kahn James, Wiener Kronish, Feldman M. D, et al. Training the Next Generation of Research Mentors: The University of California, San Francisco, Clinical \& Translational Science Institute Mentor Development Program [J]. Clinical \& Translational Science, 2009, 2(3):216-221..

[2] W. Strunk Jr., E.B. White, The Elements of Style, third ed., Macmillan, New York, 1979.

[3] Daddario, N. Macho, A. et al. Non-pungent capsaicinoids from sweet pepper synthesis and evaluation of the chemopreventive and anticancer potential.[J]. European Journal of Nutrition, 2003, 42(1):2-9.

[4] Esselman P C, Campbell D M, Cress M E, et al. Factors associated with changes in gait speed in older adults.[J]. Journals of Gerontology, 1996, 51(6):M297-302.

[5] Ronald W. Marx, Phyllis Blumenfeld, et al. Creating Usable Innovations in Systemic Reform: Scaling Up Technology-Embedded Project-Based Science in Urban Schools [J]. Educational Psychologist, 2000, 35(3):149-164.

[6] Xiao Y, Wang C, Liu T. Post-Project evaluation index system construction of oilfield surface engineering projects [J]. Journal of Liaoning Technical University, 2011.

[7] Cesar Calderon, Luis Serven. The Effects of Infrastructure Development on Growth and Income Distribution, World Bank Policy Research Working Paper, 2004: 43-47.

[8] Asian Development Bank Post-Evaluation Office. 1997. Country Synthesis of Post-Evaluation Findings in Malaysia [J]. December: 33-72.

[9] Christine F, Tramposch B. 1998.Soft opening Post-occupancy evaluation at The Papa, the Museum of New Zealand. Visitor Studies Today. 1(2): 21-29.

[10] The World Bank. 1994. Assessing Development Effectiveness [M]. Washington: 1-40. 